Niniejsza publikacja jest dostępna na licencji Creative Commons. Uznanie autorstwa-Użycie niekomercyjne-Bez utworów zależnych 3.0 Polska. Pewne prawa zastrzeżone na rzecz autora. Zezwala się na wykorzystanie publikacji zgodnie z licencja - pod warunkiem zachowania niniejszej informacji licencyjnej oraz wskazania autora jako właściciela praw do tekstu. Treść licencji jest dostępna na stronie: http://creativecommons.org/licenses/by-nc-nd/3.0/pl/

Lingwistyka Stosowana 19: 4/2016, 33-46

\author{
Elżbieta GAJEK
}

Uniwersytet Warszawski

\title{
Technologie mobilne w nauczaniu języków obcych - w opinii nauczycieli
}

\begin{abstract}
:
Mobile technologies in teaching foreign languages - in the opinions of teachers

Access to resources and educational materials via mobile devices and applications influences strategies of foreign language teaching and learning. Applications are particularly useful in teaching and learning vocabulary and pronunciation and in the development of reading and listening. Although they are effective in individual learning, there are controversies in the case of applying Mobile Technologies (MT) in a language class. The text presents the conditions that enable or hinder the introduction of MT into formal language education as well as the results of a study among in-service teachers. The teachers know the educational potential of MT, however, in class, they use mainly dictionaries and freeware applications. At primary level they use games.
\end{abstract}

\section{Wstęp}

Wykorzystanie TM w nauczaniu i uczeniu się języków jest stosunkowo nowe, skupia uwagę badaczy od 20 lat (zob. A. Kukulska-Hulme/ L. Shield 2008, C. Kennedy/ M. Levy 2008) co nawet w porównaniu z półwieczem prac nad stosowaniem technologii informacyjnych i komunikacyjnych jest okresem bardzo krótkim. Tak więc nauczyciel, który obserwuje rozwój technologii cyfrowych i często sam ich używa prywatnie znajduje się sytuacji, w której z jednej strony dostrzega potencjał TM w uczeniu się i nauczaniu języków obcych. W ofercie wydawnictw znajdują się liczne materiały adresowane do użytkowników TM. Podstawa programowa zachęca do stosowania TIK (technologie informacyjne i telekomunikacyjne) w nauczaniu języków. Z drugiej strony nauczyciel ma niewielki dostęp do przykładów wykorzystania TM na lekcji i poza nią. Próba zastosowania TM wymaga rozwiązania wielu problemów sprzętowych dotyczących rodzaju urządzenia, systemu operacyjnego. Szkoła zwykle nie zapewnia wszystkim uczniom w klasie dostępu do TM, pojawiają się więc dylematy moralne, czy i w jakim stopniu można wykorzystywać urządzenia będące własnością prywatną uczniów. Nie należy zakładać, że każdy uczeń ma takie urządzenie, więc istnieje zagrożenie dyskryminacją ze względu na status ekonomiczny. Nauczyciel nie 
także zwykle dostępu do najnowszych teorii wyjaśniających zjawiska uczenia języków z wykorzystaniem TM oraz do wyników badań efektywności stosowania TM w uczeniu i nauczaniu języków. Metaanaliza badań opublikowanych w latach 19942014 wskazuje, że kompetencje nauczyciela sprzyjają stosowaniu TM w nauczaniu języków obcych, ale ich brak nie jest silnym czynnikiem negatywnym (zob. J. Burston 2014).

Poniżej przedstawione zostaną podejścia teoretyczne do TM w edukacji językowej oraz wyniki badań prowadzonych wśród czynnych nauczycieli języków obcych (670 respondentów).

\section{Technologie mobilne w edukacji językowej}

Publikowane prace podkreślają zwykle zalety TM, które „mogą być używane spontanicznie, osobiście, w odniesieniu do konkretów, przenośnie, wszechobecnie (dostępne wszędzie) i w sposób przenikający życie codzienne (w sposób zintegrowany z codziennymi zajęciami, że jest to trudno zauważalne" (zob. A. Kukulska-Hulme 2005: 2). Badania potwierdzają pozytywne opinie uczących się języków o przydatności technologii mobilnych do uczenia się (zob. V. Demouy/ A. Kukulska-Hulme 2010, A. Kukulska-Hulme/ L. Shield 2008). Jednak badania G. Stockwella $(2008,2010)$ prowadzone w Japonii wskazują, że jeśli uczniowie mają wybór pomiędzy komputerem stacjonarnym a urządzeniem mobilnym zdecydowanie wybierają komputer stacjonarny. J. Burston (2014: 303) zauważa, że nieliczne z opisywanych w ciągu dwudziestu lat projektów mają charakter innowacyjny, a tylko kilka rewolucyjny. Ponadto niewiele osiągnięć zostaje na stałe włączone do programu nauczania, odbywa się to na zasadzie dobrowolnej, indywidualnej decyzji autora. A. Palalas (2009, 2011a; 2011b) w badaniach nad rozwojem sprawności słuchania i mówienia prowadzonych w Kanadzie wskazuje na potrzebę zmiany podejścia do wykorzystania TM na bardziej ekologiczne zapewniające takie planowanie zadań aby użycie języka wynikało z kontekstu, aby było częścią aktywności ucznia. D. Hoven i A. Palalas (2011) proponują wykorzystanie koncepcji konstruktywizmu ekologicznego do analizy zjawisk uczenia się z wykorzystaniem TM. Konstruktywizm ekologiczny (zob. M. A. K. Halliday 1993/ G. Wells 1994) pozwala na holistyczne spojrzenie na zjawiska uczenia się języków obcych z uwzględnieniem systemów językowych dostępnych dla ucznia, procesów uczenia się języków, interakcji pomiędzy uczestnikami uczenia się. Konstruktywizm ekologiczny proponuje także podejście badawcze do odkrywania wzajemnych relacji pomiędzy tymi powyżej wymienionymi zjawiskami. Obejmuje zarówno indywidualne procesy uczenia w ujęciu J. Piageta (1971) jak i konstruktywizm społeczny L. Wygotskiego $(1962,1978)$ wskazujący na znaczenie interakcji społecznych w uczeniu się języków, a także szeroko rozumianą rolę środowiska, które także wpływa na te procesy przyswajania języków obcych (zob. W. S. E. Lam/ C. Kramsch 2003: 144). Uczenie się polega na tym, że uczniowie wykorzystując znane struktury i słownictwo tworzą potrzebne im w danej chili wyrażenia, czyli używają języka, który jest im potrzebny w konkretnej sytuacji. Treści i struktury językowe wynikają z interakcji i działań w środowisku językowym, które obejmuje zarówno zasoby cyfrowe z których uczeń korzysta, jak i interakcje odbywające się za pośrednictwem 
narzędzi cyfrowych (zob. D. Hoven 1997/ B. A. Lafford 2009/ L. van Lier 2000). Holistyczne podejście ekologiczne włącza więc również konektywizm (zob. S. Downes 2007/ G. Siemens 2005) wskazujący na rolę TIK w uczeniu się, podkreśla on znaczenie sytuacji, w których uczeń uczestniczy oraz rolę podejmowania decyzji. Pomimo przedstawionych powyżej odwołan do teorii uczenia się i przyswajania języków liczni autorzy zwracają uwagę na brak teorii uczenia się mobilnego, które odróżniałyby ter rodzaj uczenia się od innych teorii (zob. O. Viberg/ Å. Grönlund 2012/ G. Duman/ G. Orhon/ N. Gedik 2015). Natomiast D. Parsons (2014: 219) dekonstruuje pionierskie idee wyjaśniające rolę TM w nauczaniu kwalifikując je do kategorii mitów. Jego zdaniem jednym $z$ nich jest twierdzenie, iż uczenie się zachodzi w jakimkolwiek miejscu i w jakimkolwiek czasie, czyli podkreślani wszechobecności uczenia się. Tymczasem zachodzi ono w konkretnym czasie, w konkretnej sytuacji, w ściśle określonym kontekście (zob. J. Seely Brown/ A. Collins/ P. Duguid 1989). Uczenie się jest uwarunkowane środowiskowo. Drugi mit podkreśla znaczenia uczenia się incydentalnego, jako reakcji na potrzebę uzyskania konkretnej informacji, a pomniejsza znaczenie systematycznego, przyswajania wiedzy według wcześniej opracowanego programu, a przecież obydwa sposoby uczenia są komplementarne. Trzeci mit odnosi się do uczenia się „w biegu”, które rzadko zachodzi podczas ruchu uczącego się (spacer, podróż samochodem) ponieważ czynniki rozpraszające są silne (zob. P. Doolittle 2009). Jednak wykorzystanie urządzeń mobilnych w coraz większym stopniu zależy od użytkownika integrującego uczenie się formalne i nieformalne.

\subsection{Cechy mobilności}

Mobilność w uczeniu się i nauczaniu języków obcych nie polega więc tylko na zastosowaniu cyfrowych urządzeń mobilnych, czyli dających się przenosić. Obejmuje znacznie szersze obszary, $w$ tym:

- mobilność w przestrzeni - uczenie się może odbywać się w różnych miejscach - mobilny jest uczeń wyposażony we własne spersonalizowane urządzenie - telefon, tablet, itp.;

- mobilność technologii - dostęp do treści, które są przyswajane, jest możliwy z różnych urządzeń - komputer stacjonarne, laptopy, tablety;

- mobilność w obszarze poznawczym - uczenie się ma charakter holistyczny, obejmuje jednocześnie treści językowe, niejęzykowe, techniczne. Przykładowo uczeń pobiera $\mathrm{w}$ muzeum aplikację $\mathrm{w}$ języku obcym i odsłuchuje ja przechodząc od eksponatu do eksponatu, albo pobiera aplikacje z opowiadaniem o trasie spaceru po zabytkowej części miasta, odsłuchuje ją poznając miasto i ucząc się języka;

- mobilność społeczna - partnerami uczenia się są różne osoby, nie tylko nauczyciel oraz koledzy i koleżanki z klasy, ale na przykład znajomi z serwisów społecznościowych;

- uczenie się rozproszone w czasie - świadome uczenie odbywa się w różnych miejscach nie tylko w szkole lub w domu (zob. A. Kukulska-Hulme/ M. Sharples/ M. Milrad/ I. Arnedillo-Sánchez/ V. Giasemi 2011: 159). 
Powyższe cechy mobilności wskazują więc raczej na możliwości wykorzystania TM w szeroko rozumianym środowisku edukacyjnym niż w szkole czy innej instytucji edukacyjnej. W rozważaniach o roli TM w edukacji językowej wskazywany jest często argument, że uczenie może zachodzić w różnych miejscach i czasie wybranym przez ucznia. Badania A. Palalas (2012) prowadzone w Kanadzie wskazują następujące obszary czasoprzestrzeni, w której uczeń korzysta z urządzeń mobilnych możliwej do wykorzystania na naukę języka obcego. Procenty wskazują liczbę respondentów

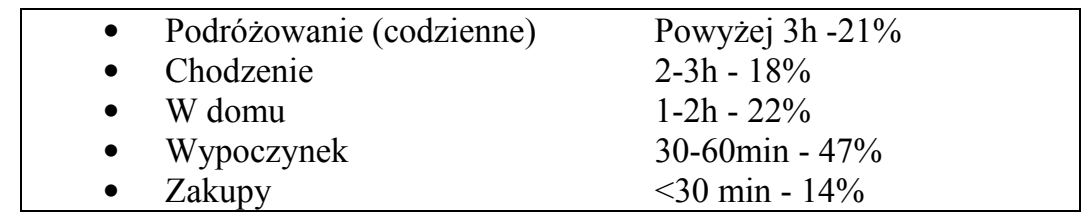

Natomiast w badaniach G. Stockwella (2010) studenci japońscy wykonywali zadania językowe głównie w domu lub na uczelni:

\begin{tabular}{|l|l|l|}
\hline Miejsce & Komputer PC & Urządzenie Mobilne \\
\hline W biegu & $0.0 \%$ & $15.4 \%$ \\
\hline Uniwersytet & $44.1 \%$ & $25.5 \%$ \\
\hline Dom & $52.5 \%$ & $43.9 \%$ \\
\hline Restauracja/Kawiarnia & $2.3 \%$ & $5.3 \%$ \\
\hline Inne & $1.1 \%$ & $4.9 \%$ \\
\hline
\end{tabular}

Tabela 1. Miejsca, w których studenci używali urzadzeń mobilnych do wykonywania zadań językowych (N=50) (zob. G. Stockwell 2010: 132).

Uczenie się języka z wykorzystaniem TM jest uwarunkowane zwyczajami, trybem życia, często konkuruje z wypoczynkiem. Najwięcej czasu na naukę mają osoby dojeżdżające codziennie do pracy czy na uczelnię.

\subsection{Rola technologii mobilnych}

W praktyce rola TM w uczeniu się i nauczaniu języków obcych polega, po pierwsze, na zmianie urządzenia. Jest to wykorzystanie urządzeń mobilnych MALL (Mobile Assisted Language Learning) (zob. G. Chinnery 2006) w taki sam sposób jak wcześniej były wykorzystywane komputery stacjonarne lub laptopy. Przykładem są słowniki cyfrowe, których dane pełnią taką samą funkcje niezależnie od nośnika i sprzętu, czy odczyt następuje z płyty CD, słownika internetowego, czy aplikacji na urządzenie mobilne.

Po drugie, zastosowanie urządzeń mobilnych zmienia strategie uczenia się i nauczania MELL (Mobile Enabled Language Learning) (zob. A. Palalas 2012). Przykładem jest sfotografowanie lub sfilmowanie obiektów we własnym otoczeniu: ulice, budynki, atrakcje miejscowości, wyposażenie wnętrza klasy lub mieszkania, zwierząt domowych albo czynności wykonywanych przez rodzinę lub przyjaciół, które następnie stanowią materiał dydaktyczny. Uczniowie podpisują lub dogrywają własne wy- 
powiedzi - na początkowym etapie nauki nazwy, potem zdania, a na poziomie zawansowanym długie teksty o charakterze narracyjnym lub, argumentacyjnym. Innym przykładem wpływu TM na strategie uczenia się jest wykorzystanie programów do uczenia się słownictwa, które wymuszają zastosowanie wbudowanych w nie strategii uczenia się, np. Quizlet lub ANKI.

\subsection{Charakterystyka uczenia się mobilnego}

Uczenie się samodzielne poza klasą i uczenie się w klasie ma zupełnie inny charakter nawet jeśli w obu miejscach wykorzystywane są TM. Potwierdzają to badania E. Gajek (2016), z których wynika, że TM są używane przez studentów jako obiekty graniczne (zob. S. L. Star/ J. Griesemer 1989/ S. L. Star 2010). Studenci używają innych funkcji tych samych urządzeń mobilnych do komunikacji, organizacji, uczenia się i rozrywki na uczelni i poza nią. W klasie nauczyciel decyduje o sposobach wykorzystania TM, określa czas wykonania ćwiczenia, monitoruje jego wykonanie i pomaga w razie trudności. Poza klasą odpowiedzialność za zarządzanie czasem nauki i wykorzystaniem funkcji urządzenia spoczywa na uczniu. Mały ekran urządzeń mobilnych wymaga przyzwyczajenia się do nawigacji pomiędzy fragmentaryczną informacją (zob. G. Stockwell 2013). Czasami interfejsy mobilne nie dają dostępu do wszystkich funkcji interfejsu stacjonarnego. Śledzenie czasu i sposobu korzystania z komputerów PC i TM pozwala wnioskować, że studenci uczą się z komputerów stacjonarnych w sposób zaplanowany, występuje związek pomiędzy otwieraniem kolejnych zadań na platformie edukacyjnej, planowanymi terminami testów i intensywnością wykonywania ćwiczeń. Natomiast uczenie się za pośrednictwem TM ma charakter spontaniczny a nie systematyczny, obywa się często wczesnym rankiem, podczas podróżowania, aby nie tracić czasu. W domu TM zapewniają dostęp do Internetu w środowisku mniej rozpraszającym uwagę ucznia (zob. G. Stockwell 2013).

\subsection{Przygotowanie zadań MELL}

Nauczyciel odpowiadając na potrzeby uczniów w konkretnej sytuacji edukacyjnej projektuje zadania, tworzy system MELLES (Mobile-Enabled Language Learning Eco System) wykorzystujący TM (zob. D. Hoven/ A. Palalas 2013). Po wyżej wspomniane były zadania $\mathrm{z}$ fotografiami własnego otoczenia dla uczniów początkujących. Zaprojektowanie zadań dla uczniów zaawansowanych w podejściu MALL nie stanowi problemu dla nauczyciela doświadczonego w stosowaniu TIK w nauczaniu. Natomiast przygotowanie zadań w podejściu MELL może budzić kontrowersje.

Przykładowe zadanie zaproponowane przez D. Hoven i A. Palalas (2013: 154) polegało na wspólnym grupowym opracowaniu multimedialnej mapy Toronto. Na wstępie uczniowie poznali przydatne do wykonania tego zadania treści i wyrażenia językowe, nagrania innych uczniów. Potem wyszli do miasta, aby sfotografować obiekty i nagrać własne opowiadanie o nich oraz o wrażeniach wyniesionych z tych miejsc, w tym także rozmowy z przypadkowo spotkanymi przechodniami. Następnie umieścili własne nagranie na wspólnej stronie internetowej, wysłuchali nagrania innych studentów i skomentowali je pisemnie na blogu. Podczas wykonywania zadania 
w terenie uczniowie mogli komunikować się za pośrednictwem TM z nauczycielem, który pozostał w klasie, jeśli zadanie było wykonywane podczas zajęć. Mogli też komunikować się z innymi uczniami. To zadanie jest przeznaczone raczej dla uczniów dorosłych, którym nauczyciel nie musi zapewnić opieki. Nawet w tym przypadku zadanie to może budzić kontrowersje, czy nagrywanie narracji sytuacyjnej podczas spaceru po mieście jest zgodne z wyobrażeniami uczniów i nauczycieli o istocie edukacji.

Kolejne zadanie proponowane przez te same autorki to teleblogowanie (Phlogging - blogging via phone). Uczniowie nagrywają podcasty a właściwie teleblogi (ang. phlogs) o swoich zainteresowaniach i dyskutują o nich z innymi (zob. D. Hoven/ A. Palalas 2013: 155).

Następne ćwiczenie to nagranie audio przewodnika po mieście. Jeden uczeń nagrywa przewodnik w tempie spaceru. W tym ćwiczeniu mogą być wykorzystane doświadczenia i sprawności językowe zdobyte w ćwiczeniu pierwszym opisanym powyżej. Drugi uczeń idzie na spacer słuchając audio przewodnika oraz wykonuje podane w nim instrukcje (D. Hoven/ A. Palalas 2013: 156).

Raporty z badań prowadzonych w wielu obszarach edukacji, nie tylko w nauczaniu języków obcych) wskazują na pozytywne efekty wykorzystania TM w nauczaniu (zob. E. Baran 2014). Podkreślane są możliwości personalizacji uczenia się oraz współpracy w klasie i poza klasą (zob. J. Cheon S. Lee/ S. M. Crooks/ J. Song 2012). Badacze wskazują na możliwości uczenia się w autentycznych warunkach i użyciem realnych dla uczniów narzędzi i z rzeczywistymi danymi (zob. K. Burden/ M. Kearney 2016, M. Kearney/ S. Schuck/ K. Burden/ P. Aubusson 2012, F. Martin/ J. Ertzberger 2013).

\section{Warunki stosowania technologii mobilnych}

Nauczyciel, który rozważa wykorzystanie TM do nauki języka obcego podejmuje decyzje odnośnie:

a) urządzeń mobilnych: sprzętu, dostępu do sieci systemu operacyjnego, oprogramowania;

b) sprawności językowych, które będą nauczane z wykorzystaniem TM;

c) interdyscyplinarności, np. na ile treści innych przedmiotów niejęzykowych mogą być materiałem do pracy nad językiem obcym;

d) etyki i bezpieczeństwa pracy, np. czy wykorzystanie prywatnych urządzeń uczniów nie dyskryminuje uczniów, którzy ich nie mają z powodów ekonomicznych; czy intensywna praca z małym ekranem nie wpływa negatywnie na wzrok ucznia (zob. E. Gajek 2013).

P. A. Ertmer (1999) wskazuje na dwa rodzaje czynników - barier - wpływających na decyzje nauczyciela: instytucjonalne - pierwszorzędne i osobiste - drugorzędne. Te pierwsze są czynnikami zewnętrznymi, takimi jak brak dostępu do sprzętu, brak czasu na planowanie, brak wsparcia technicznego i administracyjnego i brak szkoleń. Te drugie, to są czynniki wewnętrzne obejmujące postawy nauczyciela i przekonania o uczeniu się i nauczaniu, o roli technologii informacyjnej, o technikach nauczania i rutynowych czynnościach i zachowaniu w klasie oraz o akceptacji zmian lub niechęci do wprowadzania zmian. Badania prowadzone w ostatnich dekadach wskazują, że 
przekonania i postawy nauczyciela decydują o używaniu techniki (zob. H. Borko/ R. Putnam 1996, D. Dweyer/ C. Ringstaff/ J. Sandholtz 1991, S.C. Li/ T. H. Choi 2014). O ile te pierwsze są podstawowym wyzwaniem dla nauczycieli, to znaczenie tych drugich rośnie, jeśli tylko problemy infrastrukturalne zostają rozwiązane. Okazuje się jednak, że nawet zmiana przekonań nie przekłada się bezpośrednio na zmianę technik pracy z uczniami (zob. Y. Karagiorgi 2005). Ostatnie badania wskazują że kapitał społeczny szkoły, czyli współpraca nauczycieli, wzajemne zaufanie, zespołowe branie odpowiedzialności, dostęp do zasobów eksperckich, chęć podejmowania ryzyka mają większy wpływ na zmiany w korzystaniu z techniki w dydaktyce niż indywidualne przekonania nauczycieli o jej przydatności (zob. S.C. Li/ T. H. Choi 2014).

Podsumowując, podstawowym warunkiem korzystania z TM, podobnie jak z komputera stacjonarnego jest więc dostęp do sprzętu, sieci i oprogramowania oraz wsparcie techniczne i administracyjne. $Z$ faktu, że liczba używanych na świecie telefonów komórkowych przekroczyła liczbę mieszkańców globu nie wynika, że wszyscy ludzie mają telefon komórkowy najnowszej generacji, dostęp do sieci i kompetencje umożliwiające korzystanie z nich. Dlatego w szkole należy raczej myśleć o pracy grupowej - kilkoro uczniów pracuje z urządzeniem będącym własnością szkoły lub kolegi czy koleżanki.

Wiadomo, że najważniejsza dla podjęcia uczenia się jest motywacja. Jednym z mierników czynników socjologicznych wpływających na motywację do rozpoczęcia nauczania i uczenia się z TM, może być chęć stosowania osiągnięć nauki i techniki w swoim życiu obserwowana w szerokiej skali społecznej. Wyniki badań opublikowane w Eurobarometer nr 224 w 2005 roku wskazują że tylko 21\% Polaków było zainteresowanych ich wykorzystaniem w swoim życiu wobec $30 \%$ zupełnie nie zainteresowanych. Badanie Eurobarometer nr 340 z 2010 roku pokazuje, że zainteresowanie wykorzystaniem techniki w Polsce zmalało do 17\%, a liczba niezainteresowanych nią Polaków zwiększyła się do $34 \%$. W porównaniu z innymi krajami Europy niższe niż w Polsce zainteresowanie stosowaniem techniki i wyższy brak zainteresowania występuje w Portugalii, Litwie, Bułgarii i Rumunii. Postawy dominujące w społeczeństwie wpływają zarówno na indywidualne wybory strategii oraz narzędzi uczenia się i nauczania, na przekonania nauczycieli i uczniów, a także na decyzje społeczności szkolnej. Tym bardziej, że jak wspomniano wcześniej, urządzenia mobilne postrzegane są przez użytkowników jako obiekty graniczne (ang. boundary objects), które są wykorzystuje zależnie od sytuacji. Na przykład przyszli nauczyciele języków obcych inaczej używają telefonów na uczelni, a inaczej poza nią, chociaż główne kategorie: komunikacja, orientacja, uczenie się i rozrywka pozostają te same to na uczelni dominuje komunikacja tekstowa, a poza nią głosowa, orientacja na uczelni oznacza szukanie informacji o numerach sal, o terminach oddania prac, a poza nią jest to głównie orientacja w mieście (zob. E. Gajek 2016).

$\mathrm{W}$ badaniach postaw innowacyjnych nauczycieli przywoływana jest teoria skutecznego działania A. Bandury (1997), która wskazuje na znaczenie pozytywnych przekonań o własnych możliwościach wykonania zadań życiowych, kontroli nad własnymi decyzjami i działaniami. A. Bandura wskazuje na cztery czynniki wpływające 
na motywację do podejmowania działań: doświadczenie - odniesiony sukces podnosi gotowość do podejmowania kolejnych działań, modelowanie - obserwowanie sukcesów innych osób wpływa na decyzje o aktywności, wsparcie społeczne - brak zachęty pochodzący od innych osób bardziej obniża chęć działania niż zachęta ją podnosi, silne fizjologiczne reakcje na stres połączone $\mathrm{z}$ niskim poczuciem kompetencji zdecydowanie zmniejszają przekonanie o własnych możliwościach.

Nauczyciel, który chciałby stosować TM ma ograniczone możliwości modelowania innych nauczycieli już pracujących z TM. Doświadczenie musi więc zdobyć sam, wsparcie społeczne zależy głównie od postawy dyrekcji, a niskie zainteresowanie społeczne stosowaniem osiągnięć nauki i techniki także nie sprzyja stosowaniu TM. Ponadto czynniki genderowe - większość nauczycielek pomniejsza swoje kompetencje techniczne, lub rezygnuje z ich zdobywania ponieważ TIK postrzegane są jako domena męska (E. Gajek 2012) - wzmagają fizjologiczne reakcje na stres.

\section{Metodologia}

Celem badań prowadzonych wśród nauczycieli języków obcych było określenie jak oceniają swoje umiejętności w zakresie wspierania samodzielnej pracy uczniów w zakresie uczenia się języków z wykorzystaniem TM oraz na ile potrafią zastosować TM w klasie. Pytania badawcze w zakresie objętym analizą w tym artykule były następujące:

- jakim sprzętem cyfrowym dysponuje nauczyciel w szkole i prywatnie?

- czy nauczyciel potrafi pokazać uczniom jak korzystać z urządzeń mobilnych do uczenia się języków obcych?

- czy nauczyciel potrafi korzystać z urządzeń mobilnych na lekcji językowej?

- jakie materiały cyfrowe nauczyciel wykorzystuje na zajęciach językowych?

- jaka jest opinia nauczyciela o przydatności technologii informacyjnych i komunikacyjnych w nauczaniu języków obcych?

Dwa ostatnie pytania obejmowały technologie informacyjne i komunikacyjne, czyli zakres szerszy niż technologie mobilne, dlatego uzyskane wyniki służą w niniejszej analizie jako dodatkowe źródło danych pogłębiających interpretację odpowiedzi na drugi i trzeci z powyższych pytań.

Informacja o ankiecie internetowej obejmującej wiele aspektów wykorzystania TIK w nauczaniu i projektach międzynarodowych online była dystrybuowana poprzez bazę danych Fundacji Rozwoju Systemu Edukacji - program eTwinning, przy czym zachęcano nauczycieli aktywnych w programie eTwinning do przekazywania linku do ankiety koleżankom i kolegom, którzy nie są aktywnymi eTwinnerami.

W badaniu przeprowadzonym przez autorkę w 2013 roku wzięło udział 670 nauczycieli języków obcych z całego kraju, to jest 0,95\% wszystkich nauczycieli języków obcych w Polsce, w tym 16\% ze śląskiego, 11\% z mazowieckiego, od 3-6\% z każdego z pozostałych województw. Respondentami były głównie kobiety $90 \%, 10 \%$ to mężczyźni. Byli to nauczyciele: 73\% angielskiego, 20\% niemieckiego,7,5\% rosyjskiego i 4,8\% francuskiego. Pracowali we wszystkich typach szkół: 29,2\% w klasach 1-3 szkoły podstawowej, 40,1\%w klasach 4-6 szkoły podstawowej, 44,4\% w gimnazjum, $33,8 \%$ w szkołach ponadgimnazjalnych. Ze względu na sposób zbierania danych - 
ankieta internetowa - grupa ta nie może być traktowana jako reprezentatywna dla populacji nauczycieli języków w Polsce.

Dostęp do sprzętu wynosił średnio 2,88 urządzenia na respondenta, w tym: komputer stacjonarny $71,83 \%$; laptop $86,29 \%$; notebook $21,01 \%$; tablet $1,04 \%$; urządzenie mobilne 33,23\%; tablica interaktywna 58,27\%.

\section{Rezultaty}

Dwa pytania w omawianej ankiecie, skierowanej do nauczycieli dotyczyły wykorzystania urządzeń mobilnych w nauczaniu i uczeniu się języków obcych. Respondenci odpowiedzieli, że potrafią wskazać uczniom jak korzystać z urządzeń mobilnych do nauki języka: wynik średni był 1,53 w skali od -3 do 3. 62,\% respondentów udzieliło odpowiedzi 2 i 3. Wskazali także na przekonanie, że umieją wykorzystywać urządzenia mobilne na lekcji: wynik średni był $1,50 \mathrm{w}$ skali od -3 do $3.60,5 \%$ odpowiedzi to były 2 i 3. Powyższe odpowiedzi w połączeniu z odpowiedziami na inne pytania tej ankiety o stosowanie materiałów do uczenia się i nauczania języków obcych wskazują, że większość (dwie trzecie) badanych nauczycieli zna potencjał urządzeń mobilnych w edukacji językowej. Korzystają oni głównie ze słowników internetowych, i darmowych aplikacji. Nauczyciele szkół podstawowych wykorzystują gry do nauczania języka. Nauczyciele znają także ofertę wydawnictw materiałów językowych w zakresie TM.

Analiza statystyczna wyników pokazuje istotne zależności pomiędzy korzystaniem z urządzeń mobilnych a wiekiem nauczycieli, nauczanym językiem, aktywnością w serwisach społecznościowych, oraz zadaniami wspomagającymi nauczanie języków obcych.

\section{Użycie komputerów stacjonarnych i urządzeń mobilnych przez nauczycieli}

Analiza statystyczna wskazuje, że na poziomie istotności $\alpha=0,05$ odrzucamy hipotezę o braku związku między wiekiem a użyciem komputera stacjonarnego (test Chi kwadrat, $\mathrm{df}=4, \mathrm{p}=0,001$ ), użyciem urządzenia mobilnego (test Chi kwadrat, $\mathrm{df}=4$, $\mathrm{p}=0,023)$. Na poziomie istotności $\alpha=0,05$ odrzucamy hipotezę o braku związku między wiekiem nauczyciela 26-35 a użyciem komputera stacjonarnego (dokładny dwustronny test Fishera, $\mathrm{p}=0,007$ ) oraz użyciem urządzenia mobilnego (dokładny dwustronny test Fishera, $\mathrm{p}=0,001$ ). Nauczyciele w wieku 26-35 lat istotnie rzadziej korzystają z komputera stacjonarnego niż pozostali nauczyciele oraz istotnie częściej korzystają z urządzeń mobilnych. Na poziomie istotności $\alpha=0,05$ odrzucamy hipotezę o braku związku między wiekiem nauczyciela 46-55 a użyciem komputera stacjonarnego (dokładny dwustronny test Fishera, $\mathrm{p}=0,001$ ), użyciem urządzenia mobilnego (dokładny dwustronny test Fishera, $\mathrm{p}=0,023$ ). Nauczyciele w wieku 46-55 lat istotnie częściej korzystają z komputera stacjonarnego niż pozostali nauczyciele oraz istotnie rzadziej korzystają z urządzeń mobilnych. Na poziomie istotności $\alpha=0,05$ odrzucamy hipotezę o braku związku między wiekiem nauczyciela 36-45 a intensywnością użytkowania słowników elektronicznych (test Chi kwadrat, $\mathrm{df}=5, \mathrm{p}=0,016$ ). Nauczyciele w wieku 36-45 lat istotnie częściej używają słowników elektronicznych. Na poziomie 
istotności $\alpha=0,05$ przyjmujemy hipotezy o braku związku wieku nauczyciela z poszczególnymi opiniami o technice.

\section{Wykorzystanie TIK a nauczany język}

Na poziomie istotności $\alpha=0,05$ odrzucamy hipotezę o braku związku między nauczaniem języka angielskiego a wykorzystaniem TIK w formie słowników elektronicznych (test Chi kwadrat, $\mathrm{df}=5, \mathrm{p}=0,025$ ), wykorzystaniem TIK: uczniowie wykonują ćwiczenia na tablicy interaktywnej (test Chi kwadrat, $\mathrm{df}=5, \mathrm{p}<0,001$ ), oraz wykorzystaniem TIK: do gier językowych (test Chi kwadrat, $\mathrm{df}=5, \mathrm{p}=0,007$ ). Nauczyciele uczący języka angielskiego istotnie częściej korzystają ze słowników elektronicznych, tablic interaktywnych do ćwiczeń dla uczniów oraz gier językowych niż pozostali nauczyciele.

Na poziomie istotności $\alpha=0,05$ odrzucamy hipotezę o braku związku między nauczaniem języka niemieckiego a wykorzystaniem TIK: uczniowie wykonują ćwiczenia na tablicy interaktywnej (test Chi kwadrat, $d f=5, p=0,002$ ) oraz wykorzystaniem TIK: do gier językowych (test Chi kwadrat, $d f=5, p=0,026)$. Nauczyciele uczący języka niemieckiego istotnie rzadziej korzystają z tablic interaktywnych do ćwiczeń dla uczniów oraz gier językowych niż pozostali nauczyciele.

\section{Korzystanie a urządzeń mobilnych i serwisów społecznościowych}

Na poziomie istotności $\alpha=0,05$ odrzucamy hipotezę o braku związku między wykorzystaniem TIK: do komunikacji w serwisach społecznościowych a wykorzystaniem urządzenia mobilnego, (dokładny dwustronny test Fishera, $\mathrm{p}=0,001$ ). Nauczyciele wykorzystujący TIK do komunikacji w serwisach społecznościowych istotnie częściej korzystają z urządzenia mobilnego niż pozostali nauczyciele.

\section{Korzystanie ze słowników i urządzeń mobilnych}

Na poziomie istotności $\alpha=0,05$ odrzucamy hipotezę o braku związku między wykorzystaniem TIK: używam słowników elektronicznych a wykorzystaniem lapotpa (test Chi kwadrat, $d f=5, p=0,012$ ), wykorzystaniem notebook'a (test Chi kwadrat, $d f=5$, $\mathrm{p}<0,001$ ), wykorzystaniem urządzenia mobilnego (test Chi kwadrat, $\mathrm{df}=5, \mathrm{p}<0,001$ ).

Używanie urządzeń mobilnych a opinia o możliwości zastapienia nauczyciela przez komputer

Na poziomie istotności $\alpha=0,05$ odrzucamy hipotezę o braku związku między opinią: Komputer nigdy nie zastąpi nauczyciela języka a wykorzystaniem urządzenia mobilnego (test Chi kwadrat, $\mathrm{df}=6, \mathrm{p}=0,038$ ). Czyli młodzi nauczyciele, którzy wykorzystują urządzenia mobilne są przekonani, iż komputer nie zastąpi nauczyciela.

Ponadto z badań wynika, że w szkołach, w których instytucjonalne bariery techniczne zostały zminimalizowane, nauczyciele wykazują pozytywne przekonania o przydatności techniki cyfrowej, w tym technologii mobilnych w nauczaniu. Potwierdza to założenia teoretyczne wskazujące, że po zaspokojeniu potrzeb infrastrukturalnych, czyli likwidacji barier pierwszorzędnych, większego znaczenia nabierają przekonania nauczyciela. Wyniki świadczą o tym, że bariery drugorzędne zmniejszają się 
w dobrych warunkach technicznych. Jednak na praktyczne stosowanie TM w dydaktyce mają także wpływ czynniki społeczne, w tym kapitał społeczny szkoły. Zainteresowanie osiągnięciami techniki w życiu jest wśród badanych nauczycieli większe niż w całej populacji, wynik ten może być rezultatem sposobu przeprowadzenia badań. Nauczyciele wypełniali ankietę internetową, więc grupa nauczycieli, którzy nie używają TIK do celów prywatnych i zawodowych mogła być mniejsza, niż w całej populacji nauczycieli.

\section{Podsumowanie i wnioski}

Stosowanie technologii mobilnych w nauczaniu i uczeniu się języków obejmuje zarówno wykorzystanie urządzeń mobilnych w takim zakresie jak wcześniej były wykorzystywane komputery stacjonarne, jak i wprowadzanie metod uczenia się, które uwzględniają możliwości szeroko pojętej mobilności technicznej, czasoprzestrzennej i społecznej. Badania prowadzone w Kanadzie i Japonii wskazują na duży wpływ czynników psychospołecznych na podejście do stosowania TM do nauki języków. Z badań prowadzonych wśród polskich nauczycieli języków obcych wynika, że dwie trzecie z nich ma świadomość potencjału edukacyjnego, które oferują TM. Z urządzeń mobilnych korzystają głównie nauczyciele młodsi, uczący języka angielskiego. Są oni także aktywni w serwisach społecznościowych. Jednak wykorzystanie TM polega raczej na zamianie urządzeń niż na wprowadzeniu innowacyjnej metodyki nauczania. Dlatego urządzenia mobilne, laptop, notebook służą głównie jako nośniki podręcznych słowników. Natomiast wprowadzenie innowacji metodycznych wymagałaby kontrowersyjnych zmian organizacyjnych i dydaktycznych. Można sądzić, że wiele z nich nie znalazłoby uznania władz edukacyjnych i rodziców uczniów. Refleksja nad stosowaniem TM w nauczaniu języków powoduje pojawienie się nowych pytań o miejsce i rolę nauczyciela jako projektanta działań edukacyjnych uczniów oraz jako ich uczestnika. Młodzi nauczyciele, użytkownicy urządzeń mobilnych, są przekonani, że komputer nie zastąpi nauczyciela. Czy jednak jego rola będzie taka jak jest obecnie? Kolejne pytania dotyczą miejsca TM w stacjonarnej szkole oraz wizji czym jest edukacja, kierują uwagę na wiele czynników kulturowych i systemowych wpływających na działania nauczyciela, w tym preferencje uczniów jako odzwierciedlenie postaw społecznych wobec TM i wymagania władz edukacyjnych.

\section{Bibliografia}

Bandura, A. (1997), Self-efficacy: The exercise of control. New York.

Baran, E. (2014), A review of research on Mobile Learning in Teacher Education, (w:) Journal of Educational Technology \& Science, 17 (4), 17-32.

Borko, H./ R. Putnam (1996), Learning to teach, (w:) D. Berliner/ R. Calfee (red.), Handbook of educational psychology. New York, 673-708.

Burden, K./ M. Kearney (2016), Conceptualising authentic mobile learning, (w:) D. Churchill/ J. Lu/ T. Chiu/ B. Fox (red.), Mobile Learning Design: Theories and Application. Singapore, 27-42. 
Burston, J. (2014), A Survey of MALL Curriculum Integration: What the Published Research Doesn't Tell, (w:) CALICO Journal, 31 (3), 303-322.

Cheon, J./ S. Lee/ S. M. Crooks/ J. Song (2012), An investigation of mobile learning readiness in higher education based on the theory of planned behaviour, (w:) Computers \& Education, 59 (3), 1054-1064.

Chinnery G. (2006) Going to the MALL: Mobile Assisted Language Learning, (w:) Language Learning \& Technology, 10 (1), 9-16, (http://lit.msu.edu/vol10num1/emerging/default.html) (Pobrano 28.11.2016).

Demouy, V./ A. Kukulska-Hulme (2010), On the spot: Using mobile devices for listening and speaking practice on a French language programme, (w:) The Journal of Open, Distance and eLearning, 25 (3), 217-232.

Doolittle, P. (2009), iPods as mobile multimedia learning environments, (w:) H. Ryu/ D. Parsons (red.), Innovative mobile learning: techniques and Technologies. Hershey, PA.

Downes, S. (2007), What connectivism is. (http://halfanhour.blogspot.com/2007/02/what-connectivism-is.html; pobrano 28.11.2016).

Duman, G./ G. Orhon/ N. Gedik (2015), Research trends in mobile assisted language learning from 2000 to 2012, (w:) ReCALL, 27 (02), 197-216. (DOI: 10.1017/S0958344014000287) (Pobrano 21.07.2016).

Dwyer, D./ C. Ringstaff/ J. Sandholtz (1991), Changes in Teachers' Beliefs and Practices in Technology-Rich Classrooms, (w:) Educational Leadership, 48/ 8, 45-52.

Ertmer, P.A. (1999), Addressing First- and Second-Order Barriers to Change: Strategies for Technology Integration, (w:) Educational Technology Research and Development, 47 (4), 47-61.

Eurobarometer 224 Europeans, Science and Technology (2005) European Commission.

Eurobarometer 340 Science and Technology (2010). European Commission.

Gajek, E. (2012), Komputery nie tylko męska sprawa, (w:) D. Obidniak (red.), Czytanki o edukacji 1. Dyskryminacja. Warszawa, 87-106.

Gajek, E. (2013), Technologie mobilne w edukacji językowej-na przykładzie języka angielskiego, (w:) Meritum Mazowiecki Kwartalnik Edukacyjny, 4, 27-33.

Gajek, E. (2016), Mobile Technologies as Boundary Objects in the Hands of Student Teachers of Languages Inside and Outside the University, (w:) International Journal of Mobile and Blended Learning, 8/ 2 (DOI: 10.4018/IJMBL.2016040107; pobrano 28.11.2016).

Halliday, M. A. K. (1993), Towards a language-based theory of learning, (w:) Linguistics and Education, 5 (2), 93-116.

Hoven, D. (1997), Improving the management of flow of control in computer-assisted listening comprehension tasks for second and foreign language learners, Brisbane: Unpublished doctor al dissertation, University of Queensland.

Hoven, D./ A. Palalas (2011), (Re)conceptualizing design approaches for mobile language learning. (w:) CALICO Journal, 28 (3), 699-720.

Hoven, D./ A. Palalas (2013), The Design of Effective Mobile-Enabled Tasks for ESP Students: A Longitudinal Study, (w:) Learner-Computer Interaction in Language 
Education: A Festschrift in Honor of Robert Fischer, (w:) CALICO Journal, 137165.

Karagiorgi, Y. (2005), Throwing Light into the Black Box of Implementation: ICT in Cyprus Elementary Schools, (w:) Educational Media International, 42 (1), 19-32. Kennedy, C., \& Levy, M. (2008), L'italiano al telefonino: Using SMS to support beginners' language learning, (w:) ReCALL, 20 (3), 315-350.

Kearney, M./ S. Schuck/ K. Burden/ P. Aubusson (2012), Viewing mobile learning from a pedagogical perspective, (w:) Research in Learning Technology, 20 (1), 14406 - (DOI: 10.3402/rlt.v20i0/14406). (www.researchinlearningtechnology.net/index.php/rlt/article/view/14406). (Pobrano 28.11.2016).

Kukulska-Hulme, A./ L. Shield (2008), An overview of mobile assisted language learning: From content delivery to supported collaboration and interaction, (w:) ReCALL, 20/ 3, 271-289.

Kukulska-Hulme, A./ M. Sharples/ M. Milrad/ I. Arnedillo-Sánchez/ V. Giasemi (2011), The genesis and development of mobile learning in Europe, (w:) D. Parsons, (ed.) Combining e-Learning and m-Learning: New applications of blended educational resources. Hershey, PA. 151-177.

Kukulska-Hulme, A. (2005), Introduction, (w:) A. Kukulska-Hulme/ J. Traxler (red.), Mobile learning: A handbook for educators and trainers. London, 1-6.

Lafford, B. A. (2009), Toward an ecological CALL: Update to Garrett (1991), (w:) Modern Language Journal, 93 (1), 673-696.

Lam, W. S. E./ C. Kramsch (2003), The ecology of an SLA community in a computermediated environment, (w:) J. Leather/ J. Van Dam (red.), Ecology of language acquisition. Dordrecht, 141-158.

Li, S.C./ T. H. Choi (2014), Does social capital matter? A quantitative approach to examining technology infusion in schools, (w:) Journal of Computer Assisted Learning, 30, 1-16.

Martin, F./ J. Ertzberger (2013), Here and now mobile learning: An experimental study on the use of mobile technology, (w:) Computers \& Education, 68 (1), 7685.

Palalas, A. (2009), Using mobile devices to extend English language learning outside the classroom, (w:) D. Metcalf/ A. Hamilton/ C. Graffeo (red.), mlearn2009: 8th World Conference on Mobile and Contextual Learning. Proceedings. University of Central Florida, 179-183.

Palalas, A. (2011a), ESP for busy college students: Is the blend of in-class, online and mobile learning the answer? (w:) IALLT Journal of Language Learning Technologies, 41 (1), 108-136.

Palalas, A. (2011b), Mobile-assisted language learning: Designing for your students, (w:) S. Thouësny/ L. Bradley (red.), Second language teaching and learning with technology, Research-publishing.net: Voillans.

Palalas, A. (2012). Design guidelines for a Mobile-Enabled Language Learning system supporting the development of ESP listening skills (Doctoral dissertation, Athabasca University). 
Parsons, D. (2014), The Future of Mobile Learning and Implications for Education and Training, (w:) M. Ally/ T. Avgoustos, (red.), Increasing Access Through Mobile Learning. Vancouver, 217-229.

Piaget, J. (1971), Psychology and epistemology: Towards a theory of knowledge, Translated by Arnold Rosen. New York.

Seely Brown, J./ A. Collins/ P. Duguid (1989), Situated cognition and the culture of learning, (w:) Educational Researcher, 18 (1), 32 - 42

Siemens, G. (2005), Connectivism: A learning theory for the digital age. (www.itdl.org/Journal/Jan_05/article01.htm; pobrano 28.11.2016).

Star, S.L./ J. Griesemer (1989), Institutional Ecology, 'Translations' and Boundary Objects: Amateurs and Professionals in Berkeley's Museum of Vertebrate Zoology, 1907-39. (w:) Social Studies of Science 19 (3), 387-420. (DOI: 10.1177/030631289019003001; pobrano 28.11.2016).

Star, S.L. (2010), This is not a boundary object: Reflections on the origin of a concept, (w:) Science,Technology \& Human Values, 35 (5), 601-617.

Stockwell, G. (2008), Investigating learner preparedness for and usage patterns of mobile learning, (w:) ReCALL, 20 (3), 253-270.

Stockwell, G. (2010), Using mobile phones for vocabulary activities: Examining the effect of the platform, (w:) Language Learning \& Technology, 14 (2), 95-110.

Stockwell, G. (2013), Tracking Learner Usage of Mobile Phones for Language Learning Outside of the Classroom, (w:) Learner-Computer Interaction in Language Education: A Festschrift in Honor of Robert Fischer, 118-136.

Van Lier, L. (2004), The ecology and semiotics of language learning. New York.

Viberg, O./ Å Grönlund (2012), Mobile assisted language learning: A literature review, mLearn 2012, 11 th World Conference on Mobile and Contextual Learning. Helsinki.

Wygotsky, L. S. (1962). Thought and Languag. . Cambridge, MA.

Wygotsky, L. S. (1978). Mind in Society. Cambridge, MA.

Wells, G. (1994), The complementary contributions of Halliday and Vygotsky to a 'language-based theory of learning', (w:) Linguistics and Education, 6 (1), 41-90. 